\title{
The Rulemaking Authority of the Executive Branch of Government - An Analysis of Slovenian and American Theory, Legislation and Case Law
}

UDK: 342.51

Iztok Rakar

University of Ljubljana, Faculty of Administration

iztok.rakar@fu.uni-li.si

\section{ABSTRACT}

The rulemaking function of the executive branch of government is a fact of life in modern democratic states. In terms of development, the importance of secondary legislation is growing in both the quantitative and qualitative sense. Because it represents a deviation from the principle of the separation of powers, secondary legislation receives a great deal of attention in both theory and case law. From a comparative standpoint, one can note a wide range of approaches to this question. It could be said that the American approach is pragmatic and flexible, while the Slovenian approach is dogmatic and rigid. In the former, the delegation of rulemaking authority to the executive branch is not problematic provided adequate mechanisms for legal and political oversight are in place; of these mechanisms, special emphasis is placed on the procedure for shaping secondary legislation and the public's participation therein. In the latter, the executive branch is still always looked upon with distrust, which is why this approach persists in delegating as narrow and substantively precise powers as possible to the executive branch. Although the main burden of the democratic legitimization of the executive branch is still borne by the law, the importance of the procedure for shaping secondary legislation, and within its framework the possibilities for public participation, has been increasing.

Keywords: executive branch of government, secondary legislation, procedure, public participation, legitimacy

JEL: K19, K49

Rakar, I. (201 1). The Rulemaking Authority of the Executive Branch of Government An Analysis of Slovenian and American Theory, Legislation and Case Law. 


\section{Introduction}

The rulemaking function of the executive branch of government constitutes a deviation from the ideal of the principle of separation of powers, according to which the executive branch is to issue only concrete individual acts of administrative legislation in the process of public administration. In modern states, this deviation is accepted as a fact of life, as it is beyond argument that it would not be possible to make this ideal a reality because the number of matters which must be regulated, abstractly and in terms of general law, is so great and these matters so complex that they surpass the abilities of the legislature to regulate them itself through its own legislative acts.

In this regard, the authority to determine abstract and general legal rules, the so-called rulemaking authority, is divided between the legislative and executive branches of government. By way of comparison, it may be noted that there exist different models of this division. For the purpose of this contribution, the most important difference is between the model which acknowledges that the executive branch has what is called original rulemaking authority and the model which only acknowledges the derivative rulemaking authority of executive branch. The difference between the two models lies in the fact that in the second model, the executive branch may use rules to regulate only those matters specified by the legislature, and may do so only to the extent and in the manner determined by the latter. These constraints do not exist in the first model. A comparative overview reveals that a vast majority of modern legal systems are based on the so-called derivative model ${ }^{1}$, with differences existing between individual models. In this contribution, the rulemaking function of the executive branch will be analyzed using the example of the American and Slovenian legal orders. The purpose of the contribution is to identify similarities and differences between the two systems and to seek out solutions that the two models could potentially offer one another.

1 An example of the original model can be found in France, where the constitution grants the executive branch of government inherent legislative authority. Article 34 of the Constitution of France of 1958 lists the domains reserved for legislative regulation (the socalled domaine reserve); already in the Constitution, all other domains are under the authority of the executive branch (Article 37 of the Constitution of France) (Wade \& Forsyth, 2004, p. 874). 


\section{Iztok Rakar \\ The Rulemaking Authority of the Executive Branch of Government - An Analysis of Slovenian and American Theory, Legislation and Case Law}

\section{The American system}

\subsection{Introduction}

In American theory and legal practice, the question of the transfer of rulemaking authority from Congress to the executive branch of government is dealt with in the framework of the doctrine of nondelegation, which took shape on the basis of two fundamental constitutional principles - the principle of the separation of powers and the principle of checks and balances. In interpretations of the substance of this doctrine and in its use in practice, a key role was played by the case law of the Supreme Court of the United States.

\subsection{Historical foundations}

Historical development in the United States is based on foundations of a different kind than those found in most other states, where the modern state was created on the basis of a struggle between the feudal order and the middle classes, because the United States was from the very start a state of the middle classes. Although the Constitution ratified in 1787 does not explicitly mention the separation of powers ${ }^{2}$, its substance makes it undoubtedly clear that this separation is one of the fundamental constitutional principles. In line with this separation, Congress is granted the legislative function, the President is granted the executive function, and the courts are granted the judicial function. ${ }^{3}$

The question of delegating legislative powers was not even put before the Constitutional Convention, as the creators of the United States Constitution found Montesquie's classic conception of a separation of powers to be convincing and realizable. However, soon after the Constitution was adopted, it became evident that there exists a void between the norm and the needs of practice.

2 The same is true of checks and balances and administrative agencies (Strauss et al., 2003, p. 102).

3 A closer view shows that the US Constitution and other legislation in a number of important fields does not strictly differentiate the three branches, but that they overlap, which is why "checks and balances" would be a more accurate label for their mutual functioning than "separation of powers". This is confirmed by a historical overview of the viewpoints of theory, among which the views of James Madison on the point of overlapping and oversight are particularly important (Federalist Papers No. 47 and No. 48) (Brugger, 2001, pp. 212-213). 


\subsection{Legislative practice}

Congress addressed the abovementioned void by beginning to delegate a portion of its powers to the President and the federal administrative agencies he was establishing. ${ }^{4}$ The problem of delegation became especially irksome the moment Congress began establishing independent agencies, administrative agencies which were not under the direct oversight of the President, and granting them increasingly extensive (regulatory) powers. From this point on, theory speaks of the emergence of the modern administrative state ${ }^{5}$, the continued development of which has drawn a question mark over certain classic doctrines of constitutional law. 6

In all periods, Congress has widely made use of the case law of the US Supreme Court, which has taken (with two exceptions - see below) a favorable view of delegation. At the beginning of the twentieth century, authorizations were becoming increasingly broad and vague, which led to the appearance of a type of legislation which some labeled "skeleton legislation". ${ }^{7}$ In present times, in a number of cases the executive branch of government has delegated authority without any substance guidelines for orientation, and has often been satisfied with a mere formal delegation - »here's the problem - deal with it«. ${ }^{\mathbf{8}}$

4 Congress may delegate its powers directly to the President or to federal administrative agencies, regardless of whether they are directly subordinate to him or not. If powers are delegated to the President, he may transfer them to federal administrative agencies (with an executive order, for example). One example of this would be the Economic Stabilization Act 1970. In practice, authority is mostly delegated directly to federal administrative agencies, and in the framework of the latter to federal independent regulatory agencies. Institutionally, therefore, Congress has no limits when delegating authority. (Pünder, 1995, p. 80; Strauss et al., 2003, p. 72).

5 Although administrative agencies had had an important role even earlier, most theory regards the New Deal period as the turning point (Strauss et al., 2003, p. 103).

6 As one of the most important characteristics of the modern administrative state, one part of theory has labeled independent administrative agencies the "headless fourth branch of government", a label which indicates the controversial nature, from the perspective of constitutional law, of their position (see Federal Trade Commission v. Ruberoid Co., 343 U.S. 470 (1952)).

7 Similarly, in modern German theory there is talk of so-called Grundsätze-, Grundlage-, and Stammgesetz (see Zippelius \& Müller (eds.), 1989, p. 247).

8 Pünder, 1995, p. 44 and 51-52. 


\subsection{Case law}

Legislation which delegated the powers of Congress to the executive branch was from the outset challenged before the US Supreme Court. In terms of development, the case law of the US Supreme Court regarding delegated legislation can be roughly broken down into three phases: 1) shaping the doctrine of nondelegation, 2) distancing itself from this doctrine, with a brief exception during the time of the New Deal legislation, and 3) the shedding of this doctrine in present times. ${ }^{9}$

\subsubsection{Shaping the doctrine of nondelegation}

Case law at first reacted harshly to the phenomenon of delegation, citing the addage "delegata postestas non potest delegatari", which originated in England, and adopting the standpoint that Congress may not delegate its rulemaking function. This became known as the doctrine of nondelegation. ${ }^{10}$

It soon became clear that a strict separation of powers could not be implemented in practice, which is why the US Supreme Court softened the doctrine of nondelegation. In the cases The Brig Aurora ${ }^{11}$ and Field v. Clark $^{12}$ it took the stance that it is not unconstitutional delegation if the existence of certain conditions which trigger legal consequences already foreseen by the law is merely confirmed (the so-called contingency rationale) ${ }^{13}$, and in Wayman $v$. Southard ${ }^{14}$ it separated important matters from less important ones and allowed delegation in the case of the latter if it was limited to defining details. ${ }^{15}$ In the first 150 years of case law,

9 See Strauss et al., 2003, p. 66. Cf. Asimow et al. (1998, pp. 397-413), who break down the development into two phases: from Field to the New Deal, and from the New Deal to the present.

10 Brugger, 2001, p. 214; Mashaw et al., 2003, p. 59; Pünder, 1995, pp. 40-41.

1111 U.S. (7 Cranch) 382 (1813).

12143 U.S. 649 (1892).

13 Mashaw et al., 2003, p. 60; Brugger, 2001, p. 214; Strauss et al., 2003, pp. 66-67; for a critical view, Bonfield and Asimow, 1988, p. 433, feel that the Court did not abide by the principles it defended.

1423 U.S. (10 Wheat.), p. 11 sl. (1825). Although this case otherwise pertained to the delegation of rulemaking authority to the courts, it is also considered a leading case for administration (Pünder, 1995, p. 41, note 15).

15 Congress must therefore decide on the most important matters itself, and the executive branch may only work out the details (compare with German theory and the so-called Parlamentsvorbehalt or parliamentary approval). While this case was never formally overruled, in practice it is no longer important in this regard, as even when ruling on 
the US Supreme Court therefore used theories of contingency and details to uphold the validity of all of the challenged legislation. ${ }^{16}$ Although a strict, uncompromising diction was used, delegation was nonetheless upheld by minimizing its importance - one of the instruments used was the argumentation that it's not about law, but facts. ${ }^{17}$ And yet this point of view is problematic, because it is de facto about more than that - it is about value judgments as to what law is to be, which implies shaping the law and actually erasing the boundary between the creation and use of legislation. ${ }^{18}$

The formation of actual case law in the field of delegation came about only at the end of the nineteenth century, when with the emergence of modern administration the United States entered the period of the modern administrative state. Due to economic development and the growth of external trade following the Civil War, a huge increase in the need for regulation occurred. This need could not be met by Congress alone, and delegation became a matter of necessity, which in turn created a need for a clear answer to the question of the acceptability and extent of delegation. At first, the US Supreme Court was skeptical of delegation, yet it soon became clear that it would not strictly enforce its view. While in its rulings the Supreme Court underlined the existence of the doctrine of nondelegation, it gave a broad interpretation of this doctrine, and now demanded of Congress only that the purpose and substance of the legislative powers be sufficiently clear to guide the actions of the executive branch, which also enables oversight by the courts (intelligible principle/primary standard). ${ }^{19}$ The reformulated doctrine of nondelegation therefore demanded of Congress only that it clearly delineate authorizations or standards; it made judgments of the acceptability of delegation almost entirely subject to the free discretion of the US Supreme Court, as the test of the judgment of constitutional law had been

human rights, the US Supreme Court avoids setting detailed substantive limitations for Congress (Pünder, 1995, p. 49; for an opposing view, see Brugger, 2001, p. 216).

16 The first was used in cases where authority was delegated to the president for determining the conditions of international trade, and the other, which was upheld longer, for other cases of delegation (Pünder, 1995, p. 41).

17 Brugger, 2001, p. 214.

18 Strauss et al., 2003, p. 63 and 92; Gellhorn \& Levin, 2006, pp. 12-13; Asimow et al., 1998 , p. 398. For this reason, Pünder (1995, p. 41, note 23) concludes that the Supreme Court did not adhere to its own principals, which is why its rulings were said to lack logic.

19 See the case J. W. Hampton, Jr. \& Co. V. United States, 276 U. S. 394 (409) [1928]. 
imprecise and enabled different interpretations of the doctrine of nondelegation. ${ }^{20}$

Until the 1930s, the US Supreme Court did not rule that an act of delegation of legislative powers had been unconstitutional, from which it follows that the doctrine of nondelegation was considered a hollow formality. ${ }^{21}$ Due to changed economic circumstances case law soon underwent a serious test, which is why it was changed for a short time.

\subsubsection{The consistent use of the doctrine of nondelegation in the era of New Deal legislation}

In two rulings in the 1930s, the US Supreme Court ${ }^{22}$ for the first (and last) time ${ }^{23}$ ruled that an authorization had been unconstitutional. It took the stance that intelligibility of the authorization (the intelligible principle) meant that Congress must intelligibly define not only the purpose, but also the substance of the authorization. ${ }^{24}$

In Panama Refining Co. v. Ryan ${ }^{25}$ the law defined the objective of the authorization, yet the court was of the opinion that it did not set decisionmaking standards for the President. ${ }^{26}$ In the so-called Sick Chicken ${ }^{27}$ case, the court once again did not find a sufficiently intelligible standard

20 Schoenbrod, 1985, p. 1224; Pünder, 1995, pp. 42 and 44.

21 Pünder, 1995, p. 43; Brugger, 2001, p. 214; Jaffe in: Mashaw et al., 2003, p. 61; Asimow et. al., 1998, p. 398. Schoenbrod (1985, p. 1269) believes that sthe court was pretending that a law which granted wide powers did not in fact do so." Lowi (1987, p. 299) calls this process "legicide", and Secretary of State Hull stated that sthe President possesses greater power than a good man wants and a bad man should have« (from Pünder, 1995, p. 45).

22 Brugger (2001, p. 215) lists Carter v. Carter Coal Co., 298 U.S. 238 (1936) as a third case. Here, wide regulatory powers were delegated to a subject of private law.

23 Mashaw et al., 2003, p. 61 and Asimow et al., 1998, p. 399.

24 These were early cases of New Deal legislation, which soon fell out of favor along with most elements of Roosevelt's constituency (Mashaw et al., 2003, p. 61; Pünder, 1995, p. 46; Asimow et al., 1998, p. 399; Brugger, 2001, p. 214-215).

25293 U.S. 388 (1935).

26 Judge Cardozo took a different stance in this case - in his opinion, the separation of power needn't be strictly, pedantically adhered to, but must be approximated in a sensible manner and elastically adapted to the needs of the practice of administration, as future development in all its infinite diversity cannot be seen in advance (from Brugger, 2001, p. 215). This can be considered a functionalist approach to the problem of the separation of powers.

27 A.L.A. Schechter Poultry Corp. v. United States, 295 U.S. 495 (1935) - the Court ruled unanimously in this case (Mashaw et al., 2003, p. 62; Strauss et al., 2003, p. 69). 
Iztok Rakar

The Rulemaking Authority of the Executive Branch of Government - An Analysis

of Slovenian and American Theory, Legislation and Case Law

for decision-making, and furthermore warned that the wide powers which had been delegated were not linked to procedural clauses which would enable the pursuit of legal objectives such as publication, suitable hearings, and evidence-based decision-making in the formation of rules or the inclusion of legal security. ${ }^{28}$

These two decisions, which placed strict substantive demands on legislative powers, were harshly criticized by justices with liberal economic leanings since they pertained to the National Industry Recovery Act 1933, that is to the core of Roosevelt's New Deal program for overcoming the economic crisis, the essence of which was steering the economy. It has been alleged that the Court's decisions were politically motivated and that the Court therefore overstepped the limits of its jurisdiction. ${ }^{29}$

\subsubsection{The current situation - Shedding the doctrine of nondelegation}

Following the two rulings discussed above, the US Supreme Court returned to its earlier practice of allowing extensive delegation. ${ }^{30}$ Since the middle of the 1930s, it has approved all delegations ${ }^{31}$, regardless of the extent of the delegated powers ${ }^{32}$. By doing so it has practically "buried"

28 Brugger, 2001, p. 215; Mashaw et al., 2003, p. 62-63; Strauss et al., 2003, p. 70. The Court opposed the absence of any procedure for rulemaking, and also found the inclusion of dominant private producers in recommending and forming rules which would also be valid for their competitors to be questionable (Asimow et al., 1998, p. 400).

29 Pünder, 1995, pp. 46-47; Asimow et al., 1998, p. 399; Orlowski, 2005, p. 137; in the same sense, Mashaw et al., 2003, p. 63. It must be stressed that this is just one kind of court activism based on a formalistic view of the content of the constitution. Another type of activism is based on a functionalistic view of the substance of the constitution is much more common; it involves the search for techniques with which to keep challenged legislation valid (see Brown, 1991 in: Strauss et al., 2003, p. 113).

30 An overview of the viewpoints of theory shows that the reason for this change was not improved legislation, but harsh criticism on account of Court's rulings, pressure from the President to form a favorable majority in the Supreme Court, and in line with this the leaning of the majority towards flexibility when interpreting the principle of the separation of powers.

31 Regulatory authorizations for private persons are an exception (Brugger, 2001, p. 216, note 9).

32 General terms like "the public interest" have been sufficient, and sometimes there wasn't even a content standard (Brugger, 2001, p. 216; Pünder, 1995, pp. 51-52 for the same). It is significant that the rulings in Yakus v. United States (321 U.S., str. $414 \mathrm{sl}$. (1944)) and Lichter v. United States (334 U.S. (str. 742 sl. (1948)), which were made in a time of war and which confirmed an wide range of powers, are still today considered the leading rulings in the field of delegation (Pünder, 1995, p. 48). 


\section{The Rulemaking Authority of the Executive Branch of Government - An Analysis of Slovenian and American Theory, Legislation and Case Law}

the doctrine of nondelegation, which has since only appeared in separate opinions. $^{33}$

This new chapter in case law regarding rulings on delegation was once again linked with changes in the economy, this time stemming from World War Two. In the middle of the twentieth century, the US Supreme Court began to stress the importance of effective external oversight over the functioning of agencies ${ }^{34}$ and developed an interpretational technique known as the clear statement rule, which it used to rule in cases where Congress had neared the constitutional threshold for delegation, thereby creating a less drastic measure than annulling a law on the grounds that it was in violation of the doctrine of nondelegation $\left(\right.$ Kent v. Dulles $\left.{ }^{35}\right){ }^{36}$

In conclusion, the matter may be summarized by saying that although US law demands, from a theoretical standpoint, that the purpose, means, or extent of an authorization be specified, this is de facto not enforced by the US Supreme Court, which since 1935 has left decisions on the extent of delegation to Congress. Congress can therefore waive extensive powers provided that certain safeguard mechanisms are respected; when it does so, it cites the complexity of social relations. Unlike in the field of protecting human rights, in the field of delimiting authority between Congress and the executive branch the US Supreme Court has not developed a consistent theory. ${ }^{37}$

33 Two classic examples are the stances of the Levanthal circuit court in the case Amalgamated Meat Cutters v. Connally and justice Rehnquist in the so-called "Benzene Case". In these cases, the doctrine of nondelegation experienced a rebirth. Despite this, a stance favoring a ban on delegation is not dominant in the US Supreme Court (Brugger, 2001, pp. 216-217, Pünder, 1995, pp. 47-48; Asimow et al., 1998, p. 401; Mashaw et al., 2003, p. 63).

34 In this framework, an important role is played not only by standards determined by law, but also by other standards which must enable the public, the courts and Congress to judge whether an administrative agency abided by legal standards. In Yakus v. United States (321 U.S. 414 (1944)) the court stressed the importance of the self-restraint of the executive branch in the sense of setting its own standards which must be adhered to. In Amalgamated Meat Cutters v. Connally (337 F. Supp. 737 (D.D.C.1971)), this was enhanced by taking into account earlier law and practice (Strauss et al., 2003, p. 73; compare Fahey v. Mallonee (332 U.S. 245 (1947))). Furthermore, the participation of the affected public and experts in procedures for amending general legal acts also belongs in the framework of agency oversight. The key phrase is "from standards to safeguards".

35357 U.S. 116 (1958).

36 Strauss et al., 2003, p. 72.

37 Pünder, 1995, pp. 49 and 51-52; Orlowski, 2005, p. 137; Mashaw et al., 2003, pp. 64-65; Brugger, 2001, p. 218; Asimow et al., 1998, pp. 410-413. 


\subsection{Theoretical viewpoints}

The viewpoints of American theory are not uniform, and this is reflected in the stances of individual Supreme Court justices and vice versa. When reviewing theoretical viewpoints, one must keep in mind that theorists use different methodological approaches to address this question. The most common are the formalist approach and the functionalist approach. ${ }^{38}$ Formalists adhere to the literal meaning of the wording of the Constitution and the original intent of its writers, and rarely if ever take into account changed circumstances and broader objectives such as sound, effective administration, while for functionalists the sharing of powers and the establishment of mutual alliances is not problematic provided the fundamental principles of the separation of powers are not compromised. It follows that although the Constitution separates the branches of power in order to guarantee the freedom of the individual, at the same time it expects practice to connect all of this into an effective system of administration (workable government).

On these foundations, two opposing theoretical viewpoints on the constitutionality of the administrative state, the essence of which lies in strengthening the rulemaking authority of the executive branch, may now be presented. The central problem that all three main actors, that is Congress, the US Supreme Court, and theory, face is the relationship between the needs of current practice and a Constitution that is over 200 years old and that still serves as a basic standard for the (political) legitimacy of the work of bodies of state. ${ }^{39}$ To paraphrase, it is a problem of squaring the circle. Lawson for example believes that the post-New Deal administrative state is unconstitutional, and defends his views with, among other things, the fact that the doctrine of nondelegation is not enforced. ${ }^{40}$ Strauss, on the other hand, feels that it is pointless to pretend that it would be possible to clearly separate the bodies of state into three categories, and stresses that the essence lies in the way that oversight over administrative agencies is conducted by a uniform, politically accountable leadership of the executive branch, and in the existence of tensions and rivalries between all three constitutional institutions, which prevents any one of them from becoming dominant and consequently obstructing

38 For other theories, see Strauss et al., 2003, pp. 112-118.

39 Strauss et al., 2003, pp. 101-102; similarly, Mashaw et al., 2003, p. 64.

40 Lawson in: Strauss et al., 2003, p. 103. 
the will and oversight of the people. ${ }^{41}$ Lindseth concludes that the development of the administrative state in the US after World War Two points to the formation of a compromise, in accordance with which a concentration of power in the hands of the executive branch is tolerated, from the standpoint of constitutional law, provided that, on a subconstitutional level, it is subjected to a spectrum of political and legal oversight mechanisms which function as a substitute for formal structural safeguards of the principle of the separation of powers. ${ }^{42}$ One of these mechanisms is an open and accountable process for shaping secondary legislation. ${ }^{43}$

\section{The Slovenian system}

\subsection{Introduction}

The Slovenian legal order rests on the principle of the separation of powers, yet it does not enforce it in its ideal form. Following the example of other modern democratic systems, it takes account of actual circumstances and thus foresees the possibility of the executive branch of government having a rulemaking function. Limits to the latter are set by the principles of a democratic republic and rule of law and by the principle of the legality of the functioning of the executive branch (the legality principle), which is derived from the rule of law. On the basis of these theoretical guidelines, the Constitutional Court has defined the substance of these principles in greater detail in its case law.

\subsection{Historical foundations}

Before the independence of the Republic of Slovenia, its territory was a constituent part of the Socialist Federative Republic of Yugoslavia, the legal order of which made reference to human rights, but did not acknowledge them in practice. Although power in the state was organized in line with the principle of the uniformity of power, both Yugoslavian and Slovenian administrative law theory developed a very consistent theory in the field of the rulemaking function of the executive branch. The substance of this theory was quite similar to that of German theory, and its foundation was clearly defined boundaries which the executive branch

41 Strauss in: Strauss et al., 2003, p. 109 et seq.

42 Lindseth, 2004, p. 1345.

43 See Rose-Ackerman, 1994, p. 1280. 
may not cross when making rules. The independence of the Republic of Slovenia therefore does not represent a turning point in this field of legal theory, as the viewpoints previously developed by Slovenian theory were also quite suitable for the new system of administrative law. Contemporary theory took them over, and the Constitutional Court built on them with its case law.

\subsection{Legislative practice}

Statistical data show that 2,193 laws and 14,040 pieces of secondary legislation were adopted in Slovenia between the years 1991 and 2009; of the latter, 3,440 were issued by the government and 10,600 were issued by ministers, which means that in this period approximately 110 laws were issued each year, and that the ratio of secondary legislation to laws is nearly six and a half to one. ${ }^{\mathbf{4 4}}$ In terms of substance, the legislative authorizations are much more narrow and specific than is the case in American legislative practice. This is because Slovenian theory and the case law of the Constitutional Court of the Republic of Slovenia have taken a very rigid stance on this question.

\subsection{Case law}

Although the period in which the Constitutional Court of the Republic of Slovenia (hereinafter the Constitutional Court) has been ruling on the constitutionality and legality of the functioning of the executive branch of government is, in comparison to the period in which the US Supreme Court has been conducting this function, quite short, it is no less interesting and important. In this relatively short period of time, the Constitutional Court, working together with theory, has helped shape a relationship between the legislative and executive branches of government in a newly formed democratic state governed by the rule of law. An overview of case law from the Constitutional Court since 1992 shows that the Court ruled not only on whether the executive branch had adhered to the authorization it had been given for secondary legislation, but also on the extent of the powers that legislation granted the executive branch.

44 Data provided in electronic form by the Office of Legislation of the Republic of Slovenia at the author's request. For statistical data from the Socialist Federative Republic of Yugoslavia, see Horvat (1990). 


\subsubsection{Assessing the extent, transparency and specificness of legislative powers}

In the field of assessing the extent and specificness of legislative powers, one of the key decisions came in the "Abančna borzna posredniška hiša d.d." case ${ }^{45}$. In this case, the Constitutional Court concluded that the legislature had reasonable grounds for granting an administrative agency authorization to define the conditions for revoking a brokerage house's license for securities trading, thereby delegating to it the right to resolve questions which are legal matters and as such should be regulated by the legislature itself, or at the very least in regards to which the legislature should establish a basis and framework for secondary regulation.

In the "Cestno podjetje Maribor, d.d." case ${ }^{46}$, the Constitutional Court defined what the substance of an executive clause could be. Its stance was that in transferring or granting authorization for issuing executive rules, an executive clause may be more general (for example, one that does not precisely define what is to be regulated with the executive rule) or more or less precise (one that specifically defines the matter that the executive rule may regulate), whereby the decision as to which type of clause the legislature will choose in an individual instance falls within the field of its free discretion. Here it is limited only by the constitutionally defined relationship between the legislative and executive branches of government. Because the principle of the separation of powers in and of itself excludes the possibility that an administrative agency would change or independently regulate legal matters, an executive clause may not contain authorizations on the basis of which executive rules could contain clauses for which there is no prior basis in the law; in particular, agencies may not independently regulate rights and obligations.

This case is also important because of the link between the question of the extent of legislative powers and the field of secondary legislation. Specifically, the Constitutional Court took the stance that it is not in discord with the Constitution if, in the field of public orders, the legislature left the broad field of its discretion to the executive branch. In the opinion

45 Decision of the Constitutional Court of Slovenia no. U-I-287/95 of 14. 11. 1996, Official Gazette of the Republic of Slovenia, no. 68/96.

46 Decision of the Constitutional Court of Slovenia no. U-I-264/99 of 28. 09. 2000, Official Gazette of the Republic of Slovenia, no. 97/2000 and OdIUS IX, 226. 
Iztok Rakar

The Rulemaking Authority of the Executive Branch of Government - An Analysis

of Slovenian and American Theory, Legislation and Case Law

of the Court, it is not possible to judge the merits of the measures in isolation due to the dual nature of public orders (which are both authoritative and non-authoritative); these measures must be judged in the framework of the macro- and microeconomic policy which governs the entire economy of society on the one hand and with regard to the function of the state, which in procedures for public orders acts as an economic subject, on the other.

As a criterion for judging the allowable extent of legislative powers, the specific field to which the matter pertained was also taken into account in one of the most recent decisions, the "Freedom of Religion" case $^{\mathbf{4 7}}$ of 15 April 2010. In this case, the Constitutional Court stressed that the exactness of legislative clauses is linked to the meaning of the substance regulated by the law, and that this is also valid for the demand that the executive branch be bound by the law - in other words, the greater the degree to which a law affects or interferes with the individual's fundamental rights, the more restrictive and precise the legislative powers should be. ${ }^{48}$ In this regard, demands for precision and restrictiveness of legislative powers in the field of accelerating or facilitating the functioning of the state are not overly strict in the opinion of the Constitutional Court. This is especially so if the executive branch must take account of constantly changing circumstances when making decisions and must do so under the condition that the substantive basis must be adequately transparent and specific so as to prevent arbitrary decisions. ${ }^{49}$ In light of this, the Court felt that legal norms which grant the executive branch an adequate substantive basis while at the same time allowing it adequate

47 Decision of the Constitutional Court of Slovenia no. U-I-92/07 of 15. 4. 2010, Official Gazette of the Republic of Slovenia, no. 46/2010.

48 By citing Slovenian theory (Šturm (ed.), 2002, p. 872), in this decision the Constitutional Court relied on the theory of materiality (German Wesentlichkeitstheorie) developed by the German Federal Constitutional Court.

49 This is why it did not annul the clauses of Paragraph 3 of Article 24 of the Religious Freedom Act, which defines an additional possibility for guaranteeing the right to religious provision. The Constitutional Court felt that the characteristics of the field of regulation demand greater room for the discretion of the executive branch, which, due to the clear intent of such a wide power, cannot lead to arbitrary decisions. It felt that the executive branch has adequate criteria and adequate guidance in the challenged legal clause, and at the same time that it has adequate maneuvering room for reacting to changed circumstances. To state the matter concretely: the competent Ministry must take into account different situations, in particular concrete, constantly changing data about the number of incarcerated persons and their religion and guarantee these persons continuous religious provision. 


\section{Iztok Rakar \\ The Rulemaking Authority of the Executive Branch of Government - An Analysis of Slovenian and American Theory, Legislation and Case Law}

openness (breadth) for taking into account concrete, explicitly changing circumstances when dealing with secondary legislation vis-à-vis organizational questions are not discordant with the principle of legality. If we link this stance with the decision presented above, we may conclude that rigid demands for the exactness, specificness and breadth of legislative authorizations are valid for the classic authoritative (regulative) function of the state, within this category of functioning, and especially for fields pertaining to fundamental human rights and freedoms.

\subsubsection{Review of the constitutionality and legality of secondary legislation}

An overview of case law from the Constitutional Court since 1992 reveals that the main decision in the field of the substantive relationship between the law and secondary legislation, that is the legality principle, came in the "Patentna pisarna d.o.o." case of $1995 .^{50}$ The essence of the legality principle, as can be discerned from this decision, lies in the substantive link between the functioning of the executive branch and the law. The law must be a substantive basis for issuing secondary legislation and individual orders of the executive branch, and this holds for both the government and administrative agencies (so that explicit authorization would not be needed in the law); this function must be within the confines of the law both in terms of substance and as a whole. The legality principle from Paragraph 2 of Article 120 of the Constitution of the Republic of Slovenia is one of the fundamental constitutional principles; it is linked to other constitutional principles and also refers to them. The principle of democracy (Article 1 of the Constitution) states, among other things, that representatives directly elected to parliament adopt the most important decisions, in particular those that pertain to citizens. As a result, the executive branch (the government and administrative agencies) can only have a legislative function on the basis of substance and within the framework of legislation, and not on the basis of its own regulations or even on the basis of its own function within the system of the separation

50 Decision of the Constitutional Court of the Republic of Slovenia no. U-I-287/95 of 14 11. 1996, Official Gazette of the Republic of Slovenia, no. 68/96. U-I-73/94 of 25. 5. 1995, Official Gazette of the Republic of Slovenia, no. 37/95 and OdIUS IV, 51 . From a developmental standpoint, the substantive "basis" of this decision is represented by decisions in the following cases: U-I-1/92 of 9. 7. 1992, Official Gazette of the Republic of Slovenia, no. 38/92 and OdIUS I, 48, U-I-72/92 of 23. 6. 1993, Official Gazette of the Republic of Slovenia, no. 42/93 in U-I-82/92 of 11. 11. 1993, Official Gazzete of the Republic of Slovenia, no. 65/93. 
Iztok Rakar

The Rulemaking Authority of the Executive Branch of Government - An Analysis

of Slovenian and American Theory, Legislation and Case Law

of powers. In this regard, the primacy of the law as well as the primacy of the legislature also have an important role in delimiting authority between the legislative and executive branches in accordance with the principle of the separation of powers (Article 3 of the Constitution). The principle of the rule of law (Article 2 of the Constitution) demands that the legal relations between the state and its citizens be regulated by laws. These are not only used to determine a framework and basis for the administrativelegislative activities of the executive branch; these activities are to become known, transparent and foreseeable among the citizens, thus enhancing the legal protection of the latter. The principle of protecting human rights and basic freedoms (Paragraph 1 of Article 5 of the Constitution) demands that human rights and basic freedoms be limited, in accordance with the principle of democracy and the principle of the rule of law, only by the legislature at such times and to such an extent as is allowed by the Constitution, not the executive branch. At the same time, this principle is also important for the effective protection of the rights and legal interests of the individual, including effective oversight over the constitutionality and legality of individual administrative acts. According to the Constitution (Article 120), in their work, which includes issuing regulations, administrative agencies are bound by the framework determined by the Constitution and the law, and do not have the right to issue regulations without a substantive basis in the law; however, at the same time, explicit authorization is not required in the law. So-called executive clauses (legislative orders which state that such and such executive regulations must be issued within a given period of time) only mean that the legislature has not (entirely) left the issuance of executive acts to the discretion of the executive power, but has used legislation to assign it the task of regulating certain questions, and has also defined a date by which this is to be done. Because the principle of the separation of powers also excludes the possibility that an administrative agency would change or independently regulate legal matters, legal theory also takes the stance that secondary general acts should not contain clauses for which there is no prior basis in the law, and in particular that agencies may not independently regulate rights and obligations.

In the "Lovskogospodarski načrti" case ${ }^{51}$, it summarized the essence of the executive nature of secondary legislation. Accordingly, we may only

51 Decision of the Constitutional Court of the Republic of Slovenia no. U-I-228/99 of 9. 10. 2002, Official Gazette of the Republic of Slovenia, no. 91/2002 and OdIUS XI, 209. 


\section{The Rulemaking Authority of the Executive Branch of Government - An Analysis of Slovenian and American Theory, Legislation and Case Law}

speak of the execution of a law if an executive rule remains within the limits of the relationships regulated by the law. Therefore if it only describes and interprets a law, it is undoubtedly a substantively dependent act. An administrative act may also supplement a legal norm, but only insofar as this supplementation will not originally regulate social relations or originally set tasks for the state. It may only encompass that which of necessity follows from the legal norm but is not explicitly stated in it. ${ }^{\mathbf{5 2}} \mathrm{An}$ administrative regulation may also choose the way in which a task is to be accomplished, but may not originally define that task. Administrative agencies therefore do not have the right to issue regulations without a substantive basis in the law, yet an explicit authorization in the law is not required.

\subsubsection{Conclusion}

The "Patent pisarna d.o.o." decision can be considered the key decision in the field of the substantive relationship between the law and secondary legislation, as the Constitutional Court later referenced it in 20 decisions in which it either annulled or removed secondary legislation due to a violation of the principle of the legality of the functioning of the executive branch. Its most recent appearance came in the ruling in the "Use of state and regional financial assets" case $^{53}$ of 2009. Theory also regards this decision as key ${ }^{54}$.

The Constitutional Court of the Republic of Slovenia references the standpoint of Slovenian theory in its leading decision in the field of the substantive relationship between the law and secondary legislation ${ }^{55}$. These viewpoints haven't essentially changed over the past decades and

52 In decision no. U-I-305/96 of 22. 04. 1999, Official Gazette of the Republic of Slovenia, no. 36/99 and OdIUS VIII, 82, the Constitutional Court emphasized that the extent to which a piece of secondary legislation may supplement a legislative clause depends on 1) the status of the secondary legislation with which the legal material is defined in detail in the hierarchy of legislative acts; and 2) the extent of the legislative powers.

53 Decision of the Constitutional Court of the Republic of Slovenia no. U-I-84/09 of 2. 7. 2009, Official Gazette of the Republic of Slovenia, no. 55/2009. see also Decisions of the Constitutional Court of the Republic of Slovenia no. U-I-156/08 of 14. 4. 2011 and U-I-257/09 of 14. 4. 2011.

54 See Šturm, 1998, p. 167. For an overview of the content of the legality principle and case law, see Šturm (1998) and the dissenting separate opinion of judge Šturm in the case Constitutional Court no. U-I-326/97 of 4. 6. 1998.

55 See Šturm, 1998, p. 155, for example. 
Iztok Rakar

The Rulemaking Authority of the Executive Branch of Government - An Analysis

of Slovenian and American Theory, Legislation and Case Law

rely on classic German theory and constitutional court case law, and this decision is still referred to today. We may therefore conclude that we cannot speak of a development of constitutional court case law regarding the substantive relationship between the law and secondary legislation that would be comparable to the development in the United States and Germany. To state the matter differently: In the field of the substantive relationship between the law and secondary legislation, the Constitutional Court still stands by its viewpoint, the essence of which was formed by (Slovenian) theory in the 1960s.

\subsection{Theoretical viewpoints}

In terms of principles, the viewpoints of Slovenian legal theory on the relationship between the law and secondary legislation may be placed into two larger groups: the classic or rigid viewpoint and the newer or more flexible viewpoint.

The classic viewpoint, which hasn't essentially changed over the past forty years, can be summarized as follows: secondary legislation may not contain clauses that are not in the law, and in particular may not independently regulate new or special rights and obligations. The functioning of all those bodies and agencies which issue secondary legislation must, in terms of substance, be legally dependent, which means that they may only technically supplement, dissect and describe the law with secondary legislation. They may not interfere with the law in terms of substance, as this would result in the legislative function being transferred to other bodies. These demands must be adhered to as consistently as possible in all those forms of the functioning of bodies of state which are enforced in a one-sided, legally binding manner through compulsion by the authorities or even through authoritarian repression. ${ }^{56}$

The newer stance starts from the fact that the principles of the separation of powers and the legality of the functioning of the executive branch develop in parallel and stresses that an ideal model of the separation of powers, in which the legislature would reach decisions politically and the executive power would merely interpret, dissect or competently execute political decisions (laws), is not practicable, or is very

56 Šturm, 1990, p. 286. Vavpetič, Godec, Šturm and Horvat should be listed as the main administrative law theoreticians who defend this stance, and Kušej and Pavčnik as the main legal theoreticians. Besides Slovenian theoreticians, the Croatian theoretician Ivo Krbek should also be mentioned. 


\section{Iztok Rakar \\ The Rulemaking Authority of the Executive Branch of Government - An Analysis of Slovenian and American Theory, Legislation and Case Law}

distant from reality, for a number of reasons. In every legal decision, even that which is most concrete and "executive" contains some sort of valuation, which is why the relationship between an "original" and an "derived" legal norm can never be such that the secondary norm would not contain original value components. ${ }^{57}$ It would also be false to claim that secondary legislation must not regulate rights and obligations, as a regulation is by definition a legal act which contains abstract and general legal norms, and every legal norm by definition regulates rights or obligations. ${ }^{58}$ It follows that the key question is what extent of its own value judgments (i.e. how much original decision-making) may the legislature leave to the executive branch? According to the newer view, the relationship between the law and the executive branch cannot be strictly defined, which is why this view advocates looking at each case individually, whereby various circumstances must be taken into account and weighed, for which it suggests the use of a test of proportionality. ${ }^{59}$

A part of newer theory also sees a solution in the procedure for shaping secondary legislation. This procedure should be constructed in such a way that it would give secondary legislation legitimacy, and by doing so would extend the democratic political process to the level of secondary legislation. Here it points out a number of pitfalls, among which the very structure of a state explicitly founded on the principle of the separation of powers is the greatest. Regardless, it feels that the rulemaking activities of the executive branch of government have for some time been a necessary part of administrative systems, which is why it is necessary to accept the fact that directly limiting the substance of the executive branch's decisions with laws has its limits. With this in mind,

57 Referring to the conclusions of Pavčnik and Bučar, in accordance with which the process of public administration works in such a way that on no level of the process would it be possible to claim that what is taking place is decision-making free of original, that is value, content. Every decision a person makes has by definition a value component (see Virant, 1999, pp. 99-100).

58 Therefore, if one interpreted Article 84 of the Slovenian Constitution to mean that the executive branch may not regulate rights and obligations, a situation would emerge where it would be nearly impossible for the executive branch to function. Author feels that this Constitutional clause only speaks of the duty of the state assembly to use a form of the law to regulate rights and obligations (see Virant, 1999, pp. 96 and 100).

59 The matter to be weighed is on the one hand the degree of deviation from the ideal of a separation of powers and the meaning of the field of constitutional rights and freedoms, and on the other the weight of reasons given by the legislature for delegating rulemaking authority. See Virant (1999). 
Iztok Rakar

The Rulemaking Authority of the Executive Branch of Government - An Analysis

of Slovenian and American Theory, Legislation and Case Law

laws should limit the way in which decisions are made to a greater degree. In this regard, it would be necessary to achieve a working balance between substance and procedural legality, in other words a relationship which would still be in accordance with the essence of the idea of a separation of powers, that is with the system of checks and balances.

\section{Conclusion}

The complexity of modern problems demands the sharing of rulemaking authority between the legislative and executive branches of government; in neither the American nor the Slovenian legal system does the latter have a more or less free hand in rulemaking. It is characteristic of the Slovenian legal system, like the German legal system, that the focus is on the substantive relationship between the law and secondary legislation, while the American system places greater emphasis on the procedure for shaping secondary legislation. If the procedure is open and accountable, it constitutes an oversight mechanism that enables the executive branch to possess wider rulemaking authority. In the Slovenian legal system, the procedural aspect of forming secondary legislation has been gaining importance over the last decade, yet at the same time the question of the impact of procedural rules on the legality of substance and the legitimacy of secondary legislation has yet to be systematically addressed from the standpoint of legal theory. On the political and administrative levels, steps have been taken in the direction of greater openness and transparency in these procedures; on the level of theory, it will be necessary first and foremost to address the question of public participation in the formation of secondary legislation as an instrument for the democratic legitimization of the functioning of the executive branch and, consequently, as a tool that enables the broadening of the rulemaking authority of the executive branch. Here it will most of all be necessary to examine the relationship between the monist concept of democracy, from which the central role of the law in the democratic legitimization of the functioning of the executive branch is derived, and the pluralist concept, according to which the starting point is the individual and his ability to participate in public administration on all levels of decision-making.

104 Uprava, letnik IX, 3/2011 
The Rulemaking Authority of the Executive Branch of Government - An Analysis of Slovenian and American Theory, Legislation and Case Law

Iztok Rakar, LL.B. (1998), LL.M. (2004) and Ph. D. (201 1). He has been a habilitated university teacher for the field of public administration at the University of Ljubliana since 2008. At the Faculty of Administration of the University of Ljubliana, he is a senior lecturer for the first-cycle degree Professional Study Programme courses Legislative Regulation of Public Administration, Public Authorities, Company Law and Public Procurement Law and also teaches the courses Administrative Procedure and Administrative Dispute. 
Iztok Rakar

The Rulemaking Authority of the Executive Branch of Government - An Analysis

of Slovenian and American Theory, Legislation and Case Law

\section{References}

Literature

- Asimow, M., Bonfield, A. E. \& Levin, R. M. (1998). State and Federal Administrative Law (2nd. ed.). St. Paul, Minnesota: West Group.

- Bogdany, A., von (2000). Gubernative Rechtsetzung. Tübingen: Mohr Siebeck.

- Bonfield, A. E. \& Asimow, M. (1988). State and Federal Administrative Law. St. Paul, Minnesota.

- Brown, R. L. (1991). Separated Powers and Ordered Liberty. University of Pennsy/vania Law Review 139(6), 513-1566.

- Brugger, W. (2001). Einführung in das öffentliche Recht der USA (2., akt. und erw. Aufl.). München: C.H. Beck.

- Bugarič, B. (2004). Openness and transparency in public administration: challenges for public law. Wisconsin international law journal 22(3), 483521.

- Davis, K. C. (1969). A New Approach to Delegation. University of Chicago Law Review 36(4), 713-733.

- Hoffmann-Riem, W. (2005). Gesetz und Gesetzesvorbehalt im Umbruch. Zur Qualitäts-Gewährleistung durch Normen. Archiv des öffentlicen Rechts, zvezek št. 130, 5-70.

- Horvat, M. (1990). Razmerja med zakoni in abstraktnimi upravnopravnimi akti. Magistrsko delo. Ljubliana: Pravna fakulteta.

- Horvat, M. (2004). Abstraktno upravnopravno delovanje. Javna uprava 40(2), 279-306.

- Jaffe, L. L. (1965). Judicial Control of Administrative Action. V: Mashaw, J. L., Merrill, R. A. \& Shane, P. M. (2003). Administrative Law: The American Public Law System (Cases and Materials, 5th ed.), str. 61. Thomson West.

- Lawson, G. (1994). The Rise and Rise of the Administrative State. Harvard Law Review 107(6), 1231-1254.

- Lepsius, O. (1997). Verwaltungsrecht unter dem Common Law: Amerikanische Entwicklungen bis zum New Deal. Tübingen: Mohr Siebeck.

- Lindseth, P. L. (2004). The Paradox of Parliamentary Supremacy: Delegation, Democracy, and Dictatorship in Germany and France, 1920s-1950s. The Yale Law Journa/ 113(6), 1341-1415.

- Mashaw, J. L. (1997). Greed, Chaos and Governance: Using Public Choice to Improve Public Law. New Haven: Yale University Press.

106 Uprava, letnik IX, 3/2011 
- Mashaw, J. L., Merrill, R. A. \& Shane, P. M. (2003). Administrative Law: The American Public Law System (Cases and Materials, 5th ed.). Thomson West.

- Orlowski, M. C. (2005). Der Erlass von Rechtsverordnungen nach amerikanischem Recht. Die Öffentliche Verwaltung 58(4), 133-142.

- Pirnat, R. (1995). Razmišljanje o postopku sprejemanja splošnih upravnih aktov. Zbornik znanstvenih razprav, letnik LV, 241-253. Ljubljana: Pravna fakulteta.

- Pirnat, R. (2003). Postopek sprejemanja predpisov. Uprava 1(1), 64-75.

- Pünder, H. (1995). Exekutive Normsetzung in den Vereinigten Staaten von Amerika und der Bundesrepublik Deutschland. Berlin: Duncker \& Humblot.

- Rose-Ackerman,S. (1994). American Administrative Law under Siege: Is Germany a Model? Harvard Law Review 107(6), 1279-1302.

- Schoenbrod, D. (1985). The Delegation Doctrine - Could the Court give it Substance? Michigan Law Review 83(5), 1223-1290.

- Schoenbrod, D. (1993). Power without Responsibility: How Congress abuses the people through delegation. New Haven, Connecticut: Yale University Press.

- Stewart, R. B. (1975). The Reformation of American Administrative Law. Harvard Law Review 88(8), 1667-1813.

- Strauss, P. L., Todd, D. R. \& Farina, C. R. (2003). Administrative Law (rev. 10th ed.). New York, New York: Thomson West.

- Šturm, L. (1990). Reforma upravne funkcije v SFRJ v luči demokratične pravne države. Zbornik znanstvenih razprav, let. 50, 285-293. Ljubljana: Pravna fakulteta.

- Šturm, L. (1998). Omejitev oblasti: ustavna izhodišča javnega prava. Ljubliana: Nova revija.

- Šturm, L. (ur.) (2002). Komentar Ustave Republike Slovenije. Ljubliana: Fakulteta za podiplomske državne in evropske študije.

- Trute, H.-H. (2006). Die demokratische Legitimation der Verwaltung. V: Hoffmann-Riem, W., Schmidt-Assmann, E. \& Vosskuhle, A. (ur.). Grundlagen des Verwaltungsrchts (Band I), 307-390. München: Verlag C. H. Beck.

- Virant, G. (1999). Novejši pogledi na zakonitost delovanja uprave. VI. dnevi slovenske uprave. Portorož. Ljubljana: Visoka upravna šola.

- Wade, W. \& Forsyth, C. (2004). Administrative Law (9th ed.). New York: Oxford University Press.

- Ziamou, T. T. (2001). Rulemaking, Participation and the Limits of Public Law in the USA and Europe. Aldershot: Ashgate. 
Iztok Rakar

The Rulemaking Authority of the Executive Branch of Government - An Analysis

of Slovenian and American Theory, Legislation and Case Law

\section{Sources}

- A.L.A. Schechter Poultry Corp. v. United States, 295 U.S. 495 (1935)

- Amalgamated Meat Cutters v. Connally, 337 F. Supp. 737 (D.D.C. 1971)

- Carter v. Carter Coal Co., 298 U.S. 238 (1936)

- Economic Stabilization Act 1970

- Fahey v. Mallonee, 332 U.S. 245 (1947)

- Federal Trade Commission v. Ruberoid Co., 343 U.S. 470 (1952)

- Field v. Clark 143 U.S. 649 (1892)

- J. W. Hampton, Jr. \& Co. V. United States, 276 U. S. 394 (409) [1928]

- Kent v. Dulles 357 U.S. 116 (1958)

- $\quad$ Lichter v. United States, 334 U.S. (str. 742 sl. (1948))

- National Industry Recovery Act 1933

- Odklonilno ločeno mnenje ustavnega sodnika Šturma v sklepu US št. U-I326/97 z dne 4. 6. 1998

- Odločba Ustavnega sodišča Republike Slovenije št. U-I-92/07 z dne 15. 4. 2010, Uradni list RS, št. 46/2010

- Odločba Ustavnega sodišča Republike Slovenije št. U-I-1/92 z dne 9. 7. 1992, Uradni list RS, št. 38/92 in OdlUS I, 48

- Odločba Ustavnega sodišča Republike Slovenije št. U-I-228/99 z dne 9. 10. 2002, Uradni list RS, št. 91/2002 in OdIUS XI, 209

- Odločba Ustavnega sodišča Republike Slovenije št. U-I-264/99 z dne 28.09.2000, Uradni list RS, št. 97/2000 in OdIUS IX, 226

- Odločba Ustavnega sodišča Republike Slovenije št. U-I-287/95 z dne 14.11.1996, Uradni list RS, št. 68/96

- Odločba Ustavnega sodišča Republike Slovenije št. U-I-305/96 z dne 22. 04. 1999, Uradni list RS, št. 36/99 in OdIUS VIII, 82

- Odločba Ustavnega sodišča Republike Slovenije št. U-I-72/92 z dne 23. 6. 1993, Uradni list RS, št. 42/93

- Odločba Ustavnega sodišča Republike Slovenije št. U-I-73/94 z dne 25. 5. 1995, Uradni list RS, št. 37/95 in OdIUS IV, 51

- Odločba Ustavnega sodišča Republike Slovenije št. U-I-82/92 z dne 11. 11. 1993, Uradni list RS, št. 65/93

- Odločba Ustavnega sodišča Republike Slovenije št. U-I-84/09 z dne 2. 7. 2009, Uradni list RS, št. 55/2009 
- Odločba Ustavnega sodišča Republike Slovenije št. U-I-156/08 z dne 14. 4. 2011 , Uradni list RS, št. 34/2011.

- Odločba Ustavnega sodišča Republike Slovenije št. U-I-257/09 z dne 14. 4. 2011 , Uradni list RS, št. 37/2011.

- $\quad$ Panama Refining Co. v. Ryan, 293 U.S. 388 (1935)

- $\quad$ The Brig Aurora, 11 U.S. (7 Cranch) 382 (1813)

- Wayman v. Southard, 23 U.S. (10 Wheat.) (1825)

- $\quad$ Yakus v. United States, 321 U.S. 414 (1944) 